\title{
Spatial and Temporal Variations of Water Quality and Trophic Status in Sembrong Reservoir, Johor
}

\author{
Syarifah Intan Najla Syed Hashim ${ }^{1,}$ Siti Hidayah Abu Talib ${ }^{1 *}$, and Muhammad Salleh \\ Abustan $^{1}$ \\ ${ }^{1}$ Faculty of Civil and Environmental Engineering, Universiti Tun Hussien Onn, Malaysia
}

\begin{abstract}
A study of spatial and temporal variations on water quality and trophic status was conducted to determine the temporal (average reading by month) and spatial variations of water quality in Sembrong reservoir and to evaluate the trophic status of the reservoir. Water samples were collected once a month from November 2016 to June 2017 in seventeen (17) sampling stations at Sembrong Reservoir. Results obtained on the concentration of dissolved oxygen (DO), water temperature, $\mathrm{pH}$ and secchi depth had no significant differences compared to Total Phosphorus (TP) and chlorophyll-a. The water level has significantly decreased the value of the water temperature, $\mathrm{pH}$ and TP. The water quality of Sembrong reservoir is classified in Class II which is suitable for recreational uses and required conventional treatment while TSI indicates that sembrong reservoir was in lower boundary of classical eutrophic (TSI > 50).
\end{abstract}

\section{Introduction}

Reservoir is an artificial lake where water is stored. The importance of reservoir to society was expected to increase over time as population, irrigation demand and economic activity grows. Main function of reservoir was to mitigate floods in downstream plain and provide water supply. Even though modern hydraulic systems consist of many elements to appropriate both surface and groundwater supplies, in many regions reservoirs are the most important components for water supply. The quality of water resources is declining from both natural (changes in precipitation; erosion) and anthropogenic (industrial and agricultural activities) factors [1]. In addition, all reservoirs are subjected to periodic fluctuations in water levels, due to rain, hydrological regimes that are influenced by irrigation of agricultural lands and temperature changes [2]. In Sembrong reservoir, human activities from agriculture and development, pollution from septic systems and sewers, sewage sludge spreading, and other human-related activities increase the flow of both inorganic nutrients and organic substances into ecosystems thus inducing the rapid growth of plants and algae which leads to eutrophication. Thus this study will determine the

\footnotetext{
* Corresponding author: hidayaht@uthm.edu.my
} 
temporal (average reading by month) and spatial variations of water quality in Sembrong reservoir and to evaluate the trophic status of the reservoir.

\section{Materials and Methods}

Sembrong dam is located about $10 \mathrm{~km}$ from Ayer Hitam, Johor. The dam lies at the coordinate of $2^{\circ} 01^{\prime} 35^{\prime \prime}$ n - $1^{\circ} 58^{\prime} 29^{\prime \prime}$ n latitude and $103^{\circ} 09^{\prime} 32^{\prime \prime}$ - - $103^{\circ} 12^{\prime} 57^{\prime \prime}$ n longitude. The reservoir surface area is $8.5 \mathrm{~km}^{2}$, with capacity of 18 million $\mathrm{m}^{3}$ along with a catchment area of $130 \mathrm{~km}^{2}$ and dam height of $11 \mathrm{~m}$. Sembrong dam was completed in 1984 and formed part of the western johor integrated agricultural development project in the state of johor. The dam was primarily for flood mitigation but the stored water (up to rl $8.5 \mathrm{~m}$ ) is tapped by syarikat air johor for water supply. Currently, they are abstracting approximately 2 million liters per day (mld) directly from the dam for domestic water demand. The reservoir is surrounded by oil palm plantation. Other minor land use are swamp forest, modern agriculture and husbandry. There are two major tributaries flowing into the reservoir, namely Sembrong River and Merpoh River. Due to indiscriminate farming, agricultural activities and the planting of oil palm trees which covers at least $87 \%$ of the dam's $130 \mathrm{~km} 2$ catchment area, this water reservoir is slowly endangered due to eutrophication or better known as algae bloom. Three sampling zones (Z1, Z2 and Z3) were established within the reservoir area (Fig. 1). All descriptions and locations are described in Table 1.

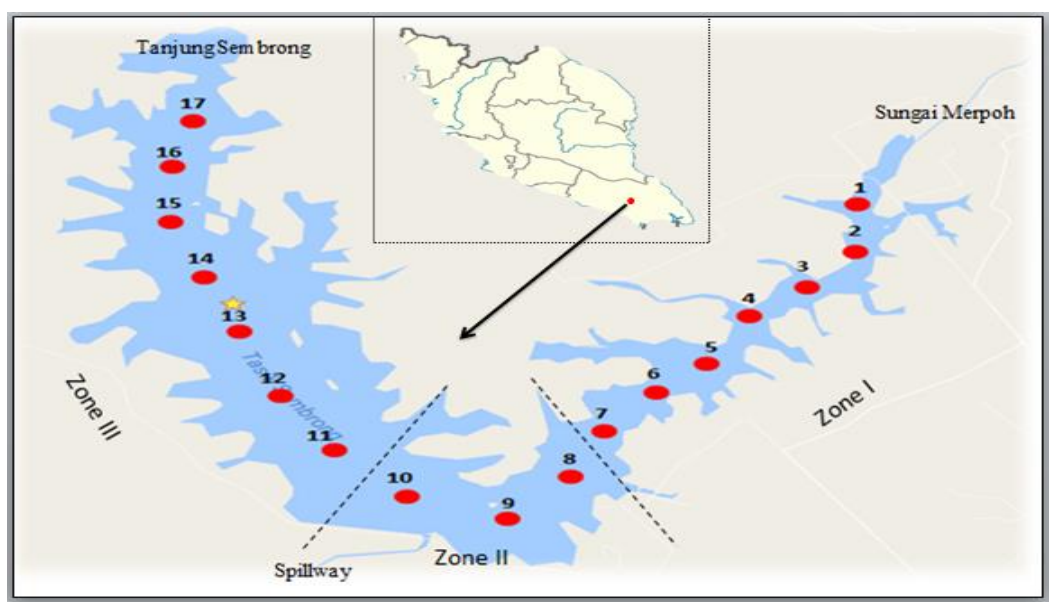

Fig. 1. Sampling Location (Z1, Z2, Z3) in Sembrong Reservoir.

\subsection{Nutrient Samples Collection and Analysis}

The water was collected about $10 \mathrm{~cm}$ below the water surface from the boat using grab sample method and stored in 1L polyethylene bottles. All samples were kept in an icebox and transported back to the laboratory for analysis. Nutrient samples were delivered to the laboratory and stored in a refrigerator within the $48 \mathrm{~h}$. Laboratory analysis for total phosphorous (TP), nitrate $\left(\mathrm{NO}_{3}{ }^{-}\right)$, ammonia nitrogen $\left(\mathrm{NH}_{4}{ }^{+}\right)$and chlorophyll-a were tested using DR 6000 Spectrophotometer and the method were outlined in the Standard Method for the Examination of Water and Wastewater (APHA, 1999). 
Table 1. General Characteristics of Sampling stations in Sembrong Reservoir.

\begin{tabular}{|c|c|c|c|}
\hline Zone & Station & Coordinates of sampling location & Description of station \\
\hline Zone I & $\begin{array}{l}1 \\
2 \\
3 \\
4 \\
5\end{array}$ & 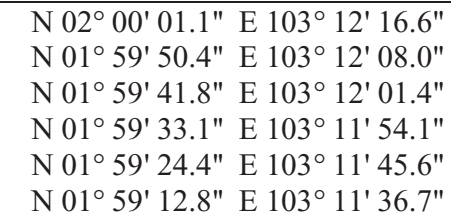 & $\begin{array}{l}\text { This station is located near to the } \\
\text { inlet of Sungai Sembrong. The } \\
\text { stations are surrounded by } \\
\text { farming and agricultural activities. } \\
\text { Riparian vegetation consists of } \\
\text { Eichhornia crassipes and grass. }\end{array}$ \\
\hline Zone II & $\begin{array}{c}7 \\
8 \\
9 \\
10 \\
11\end{array}$ & $\begin{array}{l}\mathrm{N} 01^{\circ} 58^{\prime} 58.5^{\prime \prime} \text { E } 103^{\circ} 11^{\prime} 24.7^{\prime \prime} \\
\mathrm{N} 01^{\circ} 58^{\prime} 49.2^{\prime \prime} \text { E } 103^{\circ} 11^{\prime} 19.4^{\prime \prime} \\
\mathrm{N} 01^{\circ} 58^{\prime} 52.8^{\prime \prime} \text { E } 103^{\circ} 11^{\prime} 13.1^{\prime \prime} \\
\mathrm{N} 01^{\circ} 58^{\prime} 53.4^{\prime \prime} \text { E } 103^{\circ} 11^{\prime} 06.5^{\prime \prime} \\
\mathrm{N} 01^{\circ} 59^{\prime} 03.5^{\prime \prime} \text { E } 103^{\circ} 10^{\prime} 44.7^{\prime \prime}\end{array}$ & $\begin{array}{l}\text { This station located near to the } \\
\text { spillway of reservoir. }\end{array}$ \\
\hline Zone III & $\begin{array}{l}12 \\
13 \\
14 \\
15 \\
16 \\
17\end{array}$ & 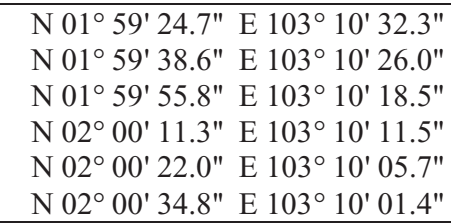 & $\begin{array}{l}\text { This station is located near to the } \\
\text { inlet of Sungai Merpoh. There } \\
\text { were many stump and dead trees } \\
\text { at this area. }\end{array}$ \\
\hline
\end{tabular}

\subsection{Carlson's Trophic State Index (TSI)}

The level of eutrophication can be determined by the trophic state index (TSI). Transparency (measured by secchi depth), total phosphorous (TP) and chlorophyll-a concentrations are used in estimating trophic status and one of the most commonly used is Carlson's Trophic State Index (TSI) (Carlson 1977) with the formula:

$$
\begin{gathered}
T S I(S D)=60-14.41 \ln (S D) \\
T S I(C h l-a)=9.81 \ln (C h l-a)+30.6 \\
T S I(T P)=14.42 \ln (T P)+4.15 \\
T S I=[T S L(T P)+T S L(C A)+T S L(S D)]
\end{gathered}
$$

3

where $\mathrm{SD}=$ Secchi depth $(\mathrm{m}), \mathrm{TP}=$ total phosphorus(ppb), and CA = chlorophyll-a (ppb).

\section{Results and discussions}

\subsection{Hydrological Data}

Fig. 2 shows the fluctuations of rainfall data and mean water level in Sembrong reservoir. The highest rainfall amount was recorded in January $2017(650 \mathrm{~mm})$ while the lowest amount was recorded in March 2017 (200 mm). Mean water level (m) recorded at Sembrong reservoir has increased from November 2016 to February 2017 and started to decreased until June 2017. The Northeast Monsoon (Monsun Timur Laut) began on November 2016 and is expected to end in March 2017 where Malaysia is expected to experience a series of heavy rainfall. The reservoir had the lowest mean water level with the value of $2.45 \mathrm{~m}$ (November 2016) and the highest water level was recorded in February $2017(3.50 \mathrm{~m})$. 


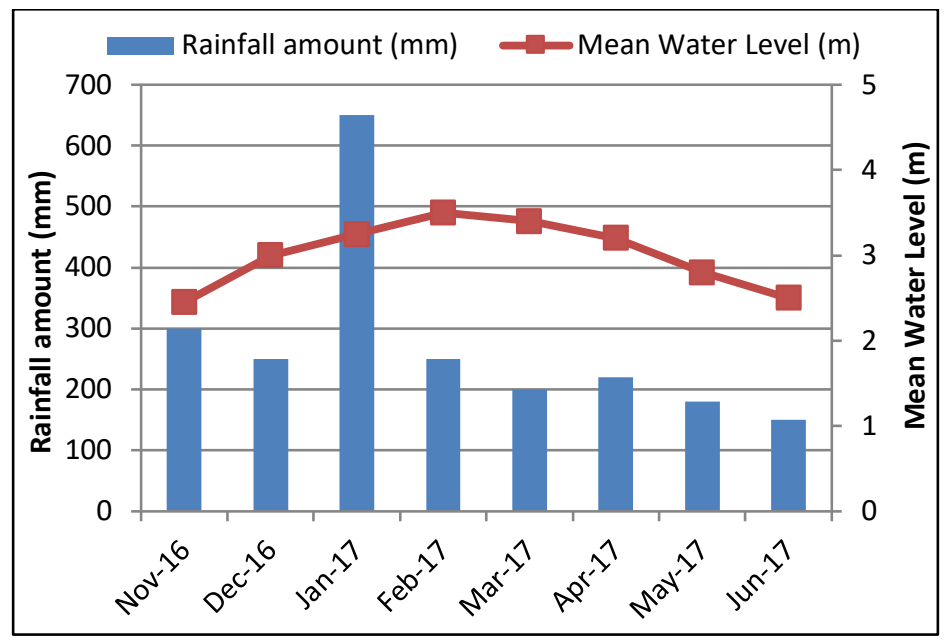

Fig. 2. Temporal variations of actual rainfall data with mean water lever in Sembrong Reservoir.

\subsection{Temporal Variations of Physiochemical Parameters}

Fig. 3 shows the average readings of all sampling stations by month from November 2016 to June 2017 of physiochemical parameters and TSI of Sembrong reservoir. Almost all lowland reservoirs are irrigation reservoirs and their hydrological regimes are significantly influenced by irrigation of agricultural lands [3]. The Sembrong reservoir is subjected to periodic fluctuations in water levels, due to rain, temperature changes and how they are operated for their functional role.

Mean concentrations of DO were ranged from 4.88 to 6.61 , which the values decreases started from January 2017 to June 2017 (Fig. 3). High values of DO in water are not unusual and mainly attributed to the direct contact of surface water with air and to the relatively higher photosynthetic activity compared to that in deeper depth of water. The DO concentration in Sembrong reservoir was regulated by the process of diffusion of oxygen from the atmosphere, photosynthetic activity, respiration and decomposition of aquatic organisms [4]. There was no significant difference in the concentration of DO among sampling stations because of the same water bodies and geographical area.

Mean water temperature had no significant difference as the values were consistent for every month at the range of $30{ }^{\circ} \mathrm{C}$ (Fig. 3). The water temperature in Sembrong reservoir was consistent throughout the year (November 2016 to June 2017) and between stations, although a drop in the temperature was observed in certain months. Cloudy and rainfall that occurred during the sampling influenced the reading of the water temperature [5]. Similar water bodies and geographical area are the reason of less variation in the water temperature among sampling stations [6].

Mean values of $\mathrm{pH}$ had less significant difference and ranged from 6.4 to 6.87 . The $\mathrm{pH}$ was decreasing every month from November 2016 to June 2017 (Fig. 3). The values of pH for both spatial and temporal were consistent throughout the study, fell around six to seven (neutral) hence suitable for most aquatic organisms. Generally, $\mathrm{pH}$ is almost the same in every layer of Sembrong reservoir due to the shallowness of the reservoir [7,8]. $\mathrm{pH}$ is a very important factor of water body for the fish culture as it controls the amount of soluble ions in the water [4]. An acidic $\mathrm{pH}$ of water reduces the growth rate, metabolic rate and other physiological activities of fishes [9], thus suggested that $\mathrm{pH}$ values varying from 6.5 to 9.0 as suitable for the normal growth of fishes. 

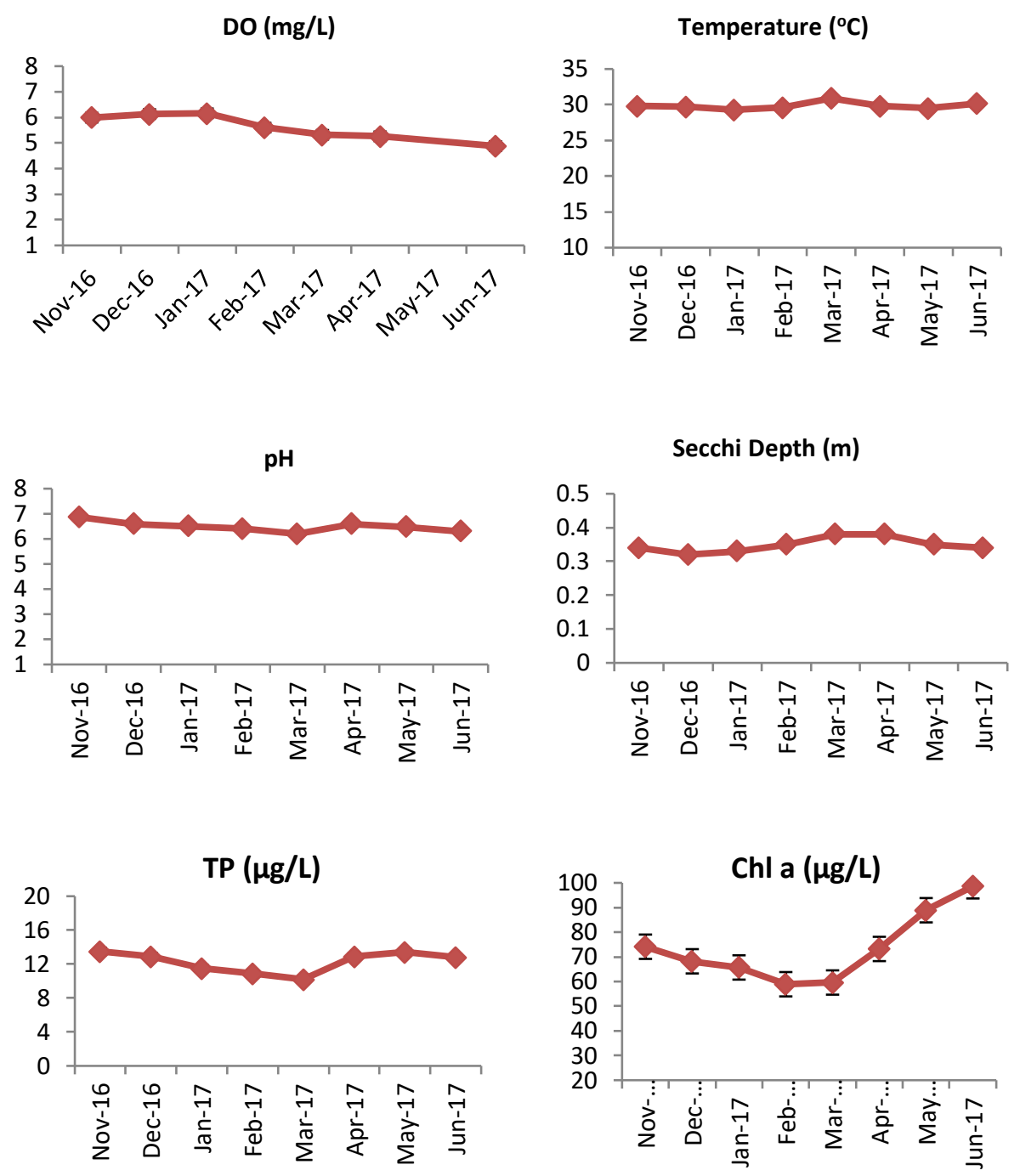

Fig. 3. The average reading of all sampling stations by month of physiochemical parameters such as DO, temperature, $\mathrm{pH}$, secchi depth, TP and Chlorophyll-a in Sembrong Reservoir.

Water clarity based on secchi depth value was consistent every month with the lowest light penetration was recorded in December $2016(0.32 \mathrm{~m})$ and the deepest light penetration was recorded in March 2017 (0.38 m). High concentrations of dissolved and particulate substances (eroded soils and nutrients) that were transported from the surrounding catchment into the reservoir after rainfall has been reducing light transmission and water clarity [10].

There was a significant difference in the mean concentration of TP between November 2016 and January 2017 (0.0185 and 0.0915 respectively). Human activities (human and animal waste, fertilizers and erosions) were the main factors increasing the concentration of the phosphorus in the water bodies [11]. The decreasing of TP was probably due to the decreased of microbial activity [12]. The secchi depth values are associated with most of aquatic plants because the chlorophyll content inside them are depending upon light availability, temperature and nutrients $[13,14]$. 


\subsection{Trophic Status Analyses}

Fig. 4 shows the TSI from November 2016 to June 2017. The TSI were less varied and belong to the same trophic state due to the location of the same water bodies and geographical areas. The TSI showed that Sembrong reservoir was in Eutrophic (TSI > 50). The result indicated that Sembrong reservoir was in lower boundary of classical eutrophy: Decreased transparency, anoxic hypolimnia during the summer, macrophyte problems evident, warm-water fisheries only and dominance of blue-green algae, algal scums probable, extensive macrophyte problems.

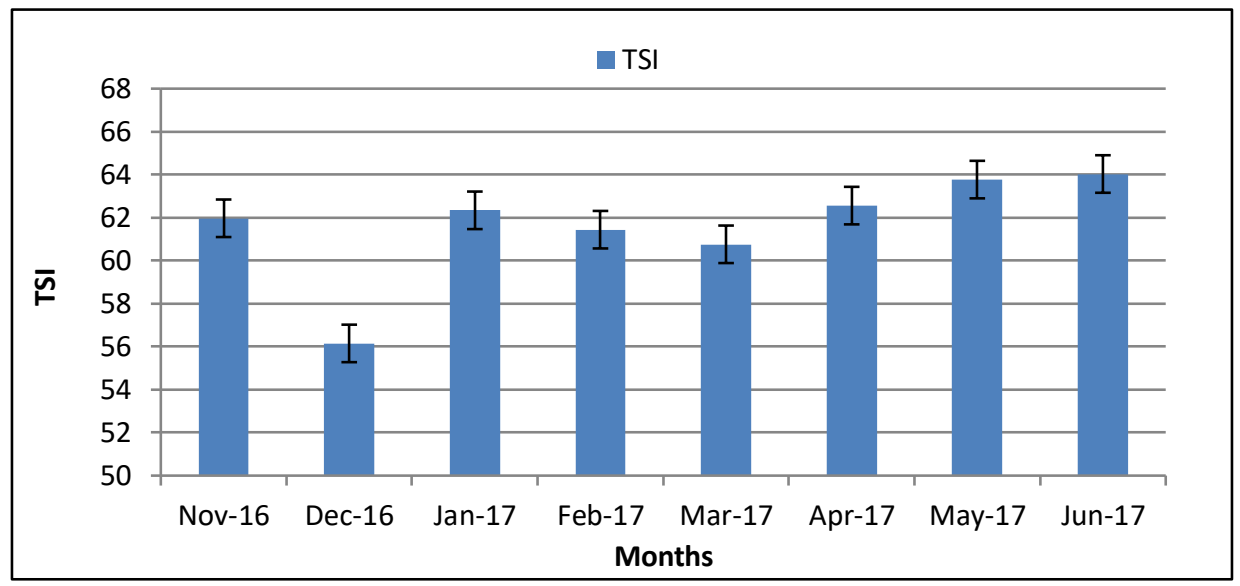

Fig. 4. Trophic Status Index (TSI) of all sampling stations by month in Sembrong Reservoir.

\begin{tabular}{|c|c|c|c|c|}
\hline TSI & $\begin{array}{r}\text { Chl-a } \\
(\mu \mathrm{g} / \mathrm{L})\end{array}$ & SD (m) & $\mathrm{TP}(\mu \mathrm{g} / \mathrm{L})$ & Attributes \\
\hline$<30$ & $<0.95$ & $>8$ & $<6$ & $\begin{array}{l}\text { Oligotrophy: Clear water, oxygen throughout the year } \\
\text { in hypolimnion }\end{array}$ \\
\hline $30-40$ & $0.95-2.6$ & $8-4$ & $6-12$ & Hypolimnia of shallower lakes may become anoxic \\
\hline $40-50$ & $2.6-7.3$ & $4-2$ & $12-24$ & $\begin{array}{l}\text { Mesotrophy: Water moderately clear; increasing } \\
\text { probability of hypolimnetic anoxia }\end{array}$ \\
\hline $50-60$ & $7.3-20$ & $2-1$ & $24-48$ & $\begin{array}{l}\text { Eutrophy: Anoxic hypolimnia, macrophyte problem } \\
\text { possible }\end{array}$ \\
\hline $60-70$ & $20-56$ & $0.5-1$ & $48-96$ & $\begin{array}{l}\text { Blue-green algae dominate, algal scums and } \\
\text { macrophyte problem }\end{array}$ \\
\hline 70-80 & $56-155$ & $0.25-0.5$ & $96-192$ & $\begin{array}{l}\text { Hypereutrophy: (light limited productivity). Dense } \\
\text { algae and macrophyte }\end{array}$ \\
\hline$>\mathbf{8 0}$ & $>155$ & $<0.25$ & $192-384$ & Algal scums, few macrophytes \\
\hline
\end{tabular}

\section{Conclusions}

The concentration of dissolved oxygen (DO), water temperature, $\mathrm{pH}$ and secchi depth had variations temporally. Meanwhile, the TP and chlorophyll-a had variations in mean reading among the sampling stations. The water quality of Sembrong reservoir is classified in Class II and TSI indicates that Sembrong reservoir was in lower boundary of classical eutrophic $(\mathrm{TSI}>50)$. 
We thank the Batu Pahat Department of Irrigation and Drainage for their hospitality, Universiti Tun Hussein Onn for funding this project under the Research University Grant (Geran Penyelidikan Kontrak Khas 2015) vot no. U422 and Research, Innovation, Commercialization, Consultancy Office UTHM (ORICC) for Postgraduate Research Grant (GPPS).

\section{References}

1. A. M. Sheela, J. Letha, S. Joseph, M. Chacko, S. P. Sanal Kumar \& J. Thomas. Lakes \& Reservoirs: Research and Management. Water quality assessment of a tropical coastal lake system using multivariate cluster, principal component and factor analysis 17, 143-159 (2012)

2. A. Duncan, J. Kubečka. Hydrobiologia 303, 11-30 (1995)

3. D. Sahoo, P. K. Smith. Journal of Hydrology 367(3), 217-227 (2009)

4. M. F. A. Mollah, M. Moniruzzaman, M. M. Rahman. Journal of the Bangladesh Agricultural University 9(2), 327-338 (2011)

5. F. J. D. M. Pedrazzi, F. T. D. Conceição, D. D. S. Sardinha, V. Moschini- Carlos, M. Pompêi. Journal of Water Resource and Protection 5, 64-71 (2013)

6. A. Sreenivasan. Internationale Revue der gesamten Hydrobiologie und Hydrographie 59(3), 327-342 (1974)

7. Department of Fisheries Malaysia (DOF). Compilation of Research Studies and Reports on Rivers, Lakes and Reservoirs in Peninsular Malaysia. Report on Limnological Study of Reservoirs in Malaysia for Inland Fisheries Development. 51117 (1993)

8. A. S. Sarnita. Symposium of Indo Pacific Fishery Commision, Colombo, Sri Lanka. Some aspects of fisheries and their development in Man-made Lakes in Indonesia with special reference to Lake Jatiluhur, West Java 17, 1-21 (1976)

9. H. S. Swingle. Proceedings of the 9th Pacific Science Congress. Relationships of pH of pond water to their suitability for fish culture 10, $72-75$ (1967)

10. C. O. Akinbile, M. S. Yusoff, S. H. A. Talib, Z. A. Hasan, W. R. Ismail, U. Sansudin. Water Science \& Technology: Water Supply. Qualitative analysis and classification of surface water in Bukit Merah Reservoir in Malaysia 13.4, 1138-1145 (2013)

11. S. C. Chapra. Surface Water-Quality Modeling. UK. (1997)

12. W. R. Ismail \& S. A. M. Najib. Lakes \& Reservoirs: Research and Management 16, 179-184 (2011)

13. W. T. Edmondson. Limnology and Oceanography 25(2), 378-379 (1980)

14. R. G. Wetzel, G. E. Likens. Limnological Analyses (2000) 